\title{
Konstruksi Pembelajaran Sejarah Islam Berbasis Teks Kajen dan Serat Cebolek dengan Pendekatan Ways of Knowing
}

\author{
Manggara Bagus Satriya Wijaya, Hermanu Joebagio, dan Sariyatun \\ Prodi Magister Pendidikan Sejarah, Universitas Sebelas Maret (UNS), \\ Manggara.B.S.W@gmail.com
}

\begin{abstract}
Learning History in the Curriculum as a whole emphasizes the importance of collective memory so that inhibits the growth of critical reasoning in the Student. This review covers an alternative approach in teaching history subjects applied in senior high school. The use of the concept of critical questions and emancipatory models of "ways of knowing" by Juergen Habermas is a strategy taken by teachers in teaching history lessons that can arouse the critical awareness of student. In-depth research is done by qualitative method to know the activity of teachers and learners thoroughly at the time of learning about the history of Shaykh Ahmad Mutamakkin and the settlement of his case stipulated in the Kajen manuscript and Cebolek manuscript as enrichment of the material history Mataram Islamic Kingdom. The results showed that during the learning prose took place the teacher has succeeded in creating the creation of the process of emancipation in the students themselves. Such emancipation enables an increase in the interest of learners to create their own knowledge on the material discussed in a historical perspective.
\end{abstract}

Keywords: local wisdom in history, critical pedagogy in teaching history, emancpatory research.

\begin{abstract}
Abstrak
Pembelajaran Sejarah dalam Kurikulum secara keseluruhan lebih menekankan pentingnya hafalan kolektif sehingga menghambat tumbuhnya nalar kritis pada diri peserta didik. Kajian ini mengulas suatu pendekatan alternatif dalam mengajarkan mata pelajaran Sejarah yang diterapkan di SMA. Penggunaan konsep pertanyaanpertanyaan kritis dan emansipatoris model "ways of knowing" karya Juergen Habermas merupakan strategi yang ditempuh oleh guru dalam mengajarkan pelajaran Sejarah yang mampu membangkitkan gairah kesadaran kritis peserta didik. Penelitian mendalam dilakukan dengan metode kualitatif untuk mengetahui aktivitas guru dan peserta didik secara menyeluruh pada saat pembelajaran seputar riwayat Syaikh Ahmad Mutamakkin dan penyelesaian kasusnya yang termaktub didalam Teks Kajen dan Serat Cebolek sebagai pengayaan dari materi Sejarah Kerajaan Mataram Islam. Hasil Penelitian menunjukkan bahwa selama proese pembelajaran berlangsung guru telah berhasil mengkreasikan terciptanya proses emansipasi pada diri peserta didik. Emansipasi tersebut memungkinkan terjadinya peningkatan minat peserta didik untuk menciptakan pengetahuanya sendiri pada materi yang dibahas dengan perspektif historis.
\end{abstract}

Kata kunci: kearifan lokal dalam sejarah, pedagogik kritis dalam pembelajaran sejarah, emancpatory research. 


\section{PENDAHULUAN}

Sejak masa silam, Nusantara (Indonesia) telah menjadi embrio bagi kelahiran kebudayaan besar dunia. Realita geografik, kultural, dan etnikal menyebabkan Indonesia dihuni oleh ratusan suku dengan budaya yang beragam serta kepercayaan dan agama yang berbeda-beda. ${ }^{1}$ Di satu sisi heterogenitas tersebut memang secara de jure mampu bermuara pada kelahiran nation state melalui perjuangan heroik melawan kekuatan kolonial yang kala itu ingin meraih kekuasaanya kembali. ${ }^{2}$ Akan tetapi kesatuan bangsa yang dirajut dengan basis humanisme dan dibangun sejak berabad-abad silam belakangan ini keberedaanya menuai persoalan yang cukup pelik.

Memang secara umum di negara yang memiliki tingkat heterogenitas seperti Indonesia kecenderunganya ialah rawan dilanda perpecahan terutama diakibatkan oleh konflik bernuansa suku, agama dan ras (SARA). Di masa silam situasi ini terjadi akibat adanya perilaku represi terhadap golongan tertentu guna menunjukkan kewibawaan penguasa. Perilaku-perilaku semacam inilah yang menjadi kajian serius Ralf Dahrendorf dalam karyanya bertajuk Class and Class Conflict in Industry Society. Dalam karyanya Ralf mengurai kebobrokan perspektif penguasa yang selalu menjadikan kekuasaan sebagai alat untuk memaksa masyarakat untuk hidup teratur guna menjaga ketertiban umum. ${ }^{3}$ Sesungguhnya apa yang dikemukakan Ralf memang benar adanya sebab dari perilaku represi dan peminggiran (sub altern) oleh rezim otoritarian terhadap suatu golongan justru malah menyuburkan gerakan radikalisasi.

Belakangan ini di Indonesia keberadaan radikalisme dan perilaku intoleran cukup marak serta eksistensinya mulai terjadi secara masif sehingga menjadi ancaman yang cukup serius dalam kehidupan berbangsa dan bernegara. Sebetulnya situasi seperti ini bukanlah sebuah kejadian yang baru dalam perjalanan bangsa ini. Namun adanya politisasi terhadap kasus-kasus berbasis pertentangan agamalah yang menjadi headline dalam beberapa pemberitaan terakhir sehingga sensitifitasnya sangat mengusik kemapanan bertoleransi dalam kehidupan berbangsa dan bernegara. Menilik situasi terkini, bukan tidak mungkin gejolak pertentangan agama seperti di masa lampau akan kembali terulang. Di masa silam pertentangan agama seolah-olah menjadi peristiwa yang menakutkan. Bagaikan, "bara api yang tidak kunjung padam" manakala kita menyebut berlangsungnya konflik dalam skala luas yang melibatkan antar umat beragama. Sebagai contoh, berbagai tulisan-tulisan sejarah telah menjadi saksi bagaimana sebuah realita konflik tercipta yakni, tentang dahsyatnya perang salib (1096-1271

\footnotetext{
${ }^{1}$ Loombard, D., Nusa Jawa: Silang Budaya, Kajian Sejarah Terpadu bagian I: Batas-batas Pembaratan,. (Jakarta: Gramedia Pustaka Utama, 2008). 5

2 Ricklefs, M. C., Sejarah Indonesia Modern. Yogyakarta: (Gadjah Mada University Press, 2016).123

${ }^{3}$ Goldstein, L. J., "Book Reviews: Class and Class Conflict in Industry Society. Ralf Dahrendorf." Ethics 71, No 2 (1961), 142-143, accessed 14-03-2018,

https://www.journals.uchicago.edu/doi/abs/10.1086/291339
} 
M) di kawasan Eropa dan Asia barat beberapa abad silam yang bersumber dari pertentangan agama. ${ }^{4}$

Setidaknya dari catatan-catatan sejarah yang telah diuraikan menunjukkan bahwa, terjadinya friksi antar umat beragama bukanlah sebuah entitas baru. Di Indonesia sendiri setidaknya sudah beberapa kali terjadi peristiwa serupa yang mengancam kedaulatan bangsa. Tercatat di era kontemporer konflik-konflik berskala besar yang melibatkan umat beragama masih sering terjadi sehingga menimbulkan dampak psikis serta dampak material secara masif bagi para pelaku dan korbanya. Pemicunya sederhana yakni munculnya stereotype dari satu kelompok terhadap kelompok lain yang berbeda agama sehingga hal ini biasanya menjadi penyulut konflik antar umat beragama yang diikuti oleh upaya saling serang, saling membunuh, membakar rumah-rumah ibadah dan tempat-tempat bernilai bagi masing-masing pemeluk agama ${ }^{5}$. Adapun beberapa kasus aktual di Indonesia yang teridentifikasi sebagai konflik antar umat beragama ialah kerusuhan konflik Poso, kerusuhan Ambon, sengketa GKI Yasmin dan serangan Tolikara 2015 merupakan representasi dari krisis intoleransi akut yang menjangkit umat beragama di Indonesia.

Berdasarkan fakta-fakta yang ditemukan menunjukkan bahwa, mayoritas terjadinya konflik antar umat beragama di Indonesia memang lebih banyak disebabkan oleh adanya gap Informasi. 6 Sebab terjadinya gap informasi sendiri karena kecenderungan orang-orang yang lebih percaya bukan pada sumbersumber informasi terpercaya. Kecenderunganya bila sudah terjadi demikian sulit rasanya proses reinvensi tradisi dan religiusitas Islam dapat dipahami secara mendalam dan dampaknya malah mengarah pada penguatan sikap fanatisme di kalangan komunitas dan golongan tertentu. Dengan realita tersebut maka optimalisasi peran sekolah sebagai institusi pendidikan menjadi sebuah keharusan terutama dalam melawan sikap fanatisme dan perilaku intoleran yang belakangan ini kian masif serta eksistensinya mulai merongrong khebinekaan Indonesia.

Keberadaan sejarah sebagai mata pelajaran wajib di SMA memang memasuki periode krusial dewasa ini sebab ruang lingkup pengajaranya yang mencakup pemahaman mendasar tentang jati diri kebangsaan dapat digunakan untuk memperadabkan setiap insan menjadi pribadi yang arif, bijaksana, menjunjung tinggi sendi-sendi kehidupan bertoleransi serta jauh dari perilaku intoleran dan fanatisme. Mewujudkan tujuan mulia tersebut dalam tataran praktis memang bukan perkara mudah, sebab selain pemilihan materi ajar yang terlepas dari isu-isu kontroversi juga dibutuhkan kecakapan dari seorang guru dalam menekankan pentingnya pemahaman reunifikasi bagi peserta didiknya dalam menanggapi gejolak-gejolak konflik yang melanda Indonesia belakangan

\footnotetext{
${ }^{4}$ Hillenbrand, C., Perang salib: sudut pandang Islam. (Jakarta: Serambi, 2005). 67

${ }^{5}$ Yunus, F. M., Konflik Agama di Indonesia Problem dan Solusi Pemecahanya, Substantia 16, No 2 (2014), 1-12. Accessed 14-03-2018, substantiajurnal.org/index.php/subs/article/download/114/112

6 Panggabean, R., Gap Informasi Picu Konflik Agama, Islam Indonesia: Satu Islam Untuk Semua, 20 January 2014, 1-2
} 
ini. beragam cara memang bisa ditempuh untuk mencapai tujuan mulia tersebut, salah satunya ialah melalui proses reaktualisasi nilai-nilai yang terdapat pada sumber-sumber belajar berbasis local wisdom sebagai langkah edukasi moral bagi peserta didik dalam proses pembelajaran. ${ }^{7}$

Bersumber pada hasil refleksi selama mengajar di Sekolah Menengah Atas (SMA) Batik I Surakarta, peneliti berasumsi bahwa, selama ini kondisi pembelajaran sejarah belum mampu mengakomodasi potensi sumber-sumber belajar berbasis local wisdom yang sesungguhnya sarat akan pesan-pesan moral. Pemanfaatan nilai-nilai yang terkandung didalam sumber-sumber belajar tradisonal seperti Manuskrip memang, belum banyak digunakan dalam proses pembelajaran karena berbagai alasan. Situasi semacam ini menurut hemat peneliti, adalah sebuah tantangan dan peluang sebab keberedaan nilai-nilai yang terkandung dalam Manuskrip merupakan sebuah warisan dari leluhur yang bersemi di lubuk hati masyarakat sehingga relatif sulit dirubah dalam waktu singkat. Dalam khazanah kapustakan Surakarta kita mengenal berbagai macam manuskrip dengan jenis yang berbeda-beda. Salah satu yang relevan untuk digunakan sebagai materi ajar ialah manuskrip yang berbentuk piwulang karena didalamnya terdapat beberapa ajaran kautamaan hidup. Dari sekian macam manuskrip yang pernah lahir di kapustakan Surakarta agaknya tepat bahwa pemahaman resolusi konflik yang terkandung didalam Teks Kajen dan Serat Cebolek bisa digunakan untuk memperadabkan peserta agar terhindar dari kian maraknya sikap fanatisme serta perilaku intoleran yang menjangkit masyarakat Indonesia akhir-akhir ini. Resolusi konflik yang ditawarkan Teks Kajen dan Serat Cebolek mempunyai model yang kurang lebih sama dengan penyelesaian konflik yang ada di dunia pesantren.

Model yang ditempuh biasanya berdasar tahapan silaturahmi, pembahasan masalah (bahtsul masail), klarifikasi (tabayun), mediasi (hakam), dan perjanjian damai (islah) sebagai proses akhir. ${ }^{8}$ Karena itulah, pemahaman ini sangat penting dijadikan landasan untuk mewujudkan cita-cita masyarakat humanis berkemakmuran yang jauh dari perasaan fanatisme dan perilaku intoleran. Proses implementasi sederetan tahapan-tahapan resolusi konflik tersebut dalam pembelajaran sejarah tentunya bukan perkara mudah sebab objek penelitian adalah mayoritas peserta didik pada jenjang SMA yang kondisinya tentu tidak bisa disamakan dengan santri di pesantren. Oleh sebab itu, diperlukan sebuah pendekatan khusus yang mampu memfasilitasi peserta didik agar pehamaman resolusi konflik mampu meresap dan terinternalisasi dalam jiwanya.

Pendekatan yang dimaksud ialah melalui pertanyaan-pertanyaan emansipatoris model ways of knowing yang dikembangkan Juergen Habermas. Pada dasarnya etika emansipatoris menuntut suatu keterbukaan sehingga tidak

\footnotetext{
7 Sariyatun, Pengembangan Model Pendidikan Nilai-Nilai Budaya Di SMP Berbasis Tradisi Seni

Batik Klasik Surakarta. Paramita 23, No 2 (2013), 230-241. Accessed 20-04-2018, https://journal.unnes.ac.id/artikel_nju/paramita/2672

8 Muslikh, K., Samroni, I., Suprojo, B. \& Fauzi, L., Teks Kajen dan Serat Cebolek sebagai Model

Pembelajaran Resolusi Konflik: Studi Metaetika, (Yogyakarta: Kaukaba, 2011), 23. (first citation).
} 
ada dominasi satu keyakinan moral suatu lingkungan tertentu terhadap keyakinan moral lainya. Dengan kata lain pendayagunaan pertanyaan-pertanyaan emansipatoris sebagai pendekatan untuk menafsirkan teks dan realitas sosial merupakan sebuah terobosan baru dalam menjembatani ketegangan antara obyektifitas dengan subyektifitas, antara idealitas dengan realitas, serta antara teoritis dan praktis. ${ }^{9}$

Implementasi pertanyaan-pertanyaan emansipatoris model ways of knowing dalam ranah pendidikan memang erat kaitanya dengan perubahan sosial masyarakat baik berupa dinamika perkembangan individu maupun proses sosial dalam skala yang lebih luas. ${ }^{10}$ Dalam hemat peneliti, sebagaimana penuturan Azyumardi Azra menerangkan bahwa, "paradigma emansipatoris merupakan instrumen ampuh untuk melakukan perubahan dalam ranah pembelajaran sejarah yang selama ini belum maksimal dalam mengajak manusia agar memiliki kesadaran (conciousness) akan diri dan lingkunganya melalui proses pendidikan humanis. ${ }^{11}$ Dengan terintegrasinya hakekat pendidikan humanis dalam proses pembelajaran maka diharapkan mampu membangun konsepsi masyarakat madani yang jauh dari adanya unsur superioritas golongan sehingga secara tidak langsung akan menghilangkan penyekat kolektivitas manusia baik dalam entitas suku bangsa maupun sekedar kelas sosial.

\section{METODE PENELITIAN}

Penelitian ini dilaksanakan di kelas XI SMA Batik I Surakarta dengan pertimbangan bahwa nuansa pembelajaran berbasis pemahaman Islam yang telah mengakar pada sekolah ini menjadi ruang yang tepat untuk menerapkan model pembelajaran sejarah Islam emansipatoris. Selain itu, pertimbangan lain yang menjadi dasar peneliti adalah latar belakang wilayah kota Surakarta yang di masa silam pernah menjadi tempat kelahiran rennaissance kesusastraan Jawa pada awal abad ke 17 sampai dengan awal abad 19 M. Seperti diketahui bahwa, penulisan Serat Cebolek, yang dalam penelitian ini digunakan sebagai primary sources dilakukan pada masa puncak rennaissance kesusastraan Jawa oleh R.Ng. Yasadipura I. Adapun untuk keberadaan Teks Kajen sendiri memang dimunculkan untuk menjadi sumber pembanding atas kenyataan sejarah yang menimpa Syekh Mutamakkin sehingga tuduhan heretic yang disematkan pada beliau seperti yang termakhtub didalam Serat Cebolek bisa dihilangkan. ${ }^{12}$ Apabila ditinjau dengan saksama, keberadaan Informasi sejarah yang termakhtub dalam kedua teks tersebut sesungguhnya sangat layak untuk dijadikan panduan pembelajaran resolusi konflik bagi peserta didik (khususnya dalam mempelajari tata cara penyelesaian konflik menurut pandangan Islam). Dengan demikian, apa yang

\footnotetext{
9 Bertens, K., Filsafat Barat abad XX Inggris-Jerma,. (Jakartsa: Gramedia, 1990), 124

${ }^{10}$ Habermas, Jurgen, The Theory Of Communicative Action, Volume One:Reason and Rationalization of Societ,(Boston: Beacon Press, 1984), 234. (first citation).

${ }_{11}$ Azra, Azyumardi, Esai-esai Intelektual Muslim dan Pendidikan Islam, (Jakarta: Logos, 1999), 89

${ }^{12}$ Milal, Zainul Bizawie, Syekh Mutamakkin: Perlawanan Kultural Agama Rakyat, (Jakarta: pustaca compass, 2014), 87. (first citation)
} 
menjadi tujuan pada penelitian ini telah menemui kesesuaian dengan karakteristik sekolah serta tipologi kota Surakarta pada khususnya.

Penelitian ini dilaksanakan guna mendapat data mendalam tentang Implementasi model pembelajaran Sejarah Islam emansipatoris berbasis Teks Kajen Dan Serat Cebolek sehingga jenis penelitian yang digunakan dalah penelitian deskriptif kualitatif. Dikatakan deskriptif kualitatif deskriptif karena menggambarkan secara utuh dan mendalam tentang realitas sosial dan berbagai fenomena yang terjadi di masyarakat yang menjadi subjek penelitian sehingga tergambar ciri, karakter, sifat, dan model dari fenomena tersebut.

Ditinjau dari aspek yang diteliti, penelitian ini menggunakan jenis penelitian studi kasus. Studi kasus adalah suatu penelitian yang diarahkan untuk menghimpun data, mengambil makna, memperoleh pemahaman dari kasus tersebut. $^{13}$ Dengan demikian pelaksanaan penelitian dengan menggunakan metode studi kasus adalah menggali informasi sebanyak-banyaknya dan sedalamdalamnya kemudian mendeskripsikannya dalam bentuk naratif sehingga memberikan gambaran secara utuh tentang fenomena yang terjadi.

Penelitian studi kasus ini menggunakan pendekatan terpancang karena sasaran dan tujuan serta masalah yang akan diteliti sudah ditetapkan sebelum terjun ke lapangan. Studi kasus terpancang merupakan suatu perangkat penting untuk memfokuskan suatu inkuiri pada studi kasus. Dalam penelitian ini terfokus pada Implementasi model pembelajaran yang terintegrasi nilai-nilai Teks Kajen dan Serat Cebolek. Oleh sebab itu, objek penelitian hanya terdapat satu karakteristik, sehingga disebut tunggal. Dengan demikian, penelitian ini ditinjau dari objeknya termasuk studi kasus tunggal terpancang. Adapun data dari penelitian ini akan digali dari berbagai sumber, antara lain:

1. Informan atau narasumber,

Informan dalam penelitan ini terdiri dari guru Sejarah, Kepala Sekolah, Wakil Kepala Sekolah bidang Kurikulum, dan perwakilan peserta didik kelas X SMA Batik I Surakarta.

2. Tempat, peristiwa atau aktivitas

Tempat, peristiwa atau aktivitas yaitu kegiatan pembelajaran Sejarah di kelas XI SMA Batik I Surakarta. Data yang diperoleh adalah dari aktivitas pembelajaran sehingga dapat digunakan untuk mengetahui tentang kegiatan pembelajaran yang selama ini berlangsung di SMA Batik I Surakarta.

3. Dokumen

Dalam penelitian ini menggunakan dokumen berupa informasi tertulis dalam bentuk silabus, RPP, dan buku pegangan guru untuk pembelajaran Sejarah kelas XI SMA Batik I Surakarta.

\footnotetext{
${ }^{13}$ Sukmadinata, Nana Syaodih, Metode Penelitian Pendidikan, (Bandung: PT Remaja Rosdakarya, 2013), 45
} 


\section{HASIL DAN PEMBAHASAN}

\section{Paradigma Pembelajaran Sejarah Lokal berdasarkan Kurikulum 2013}

Semenjak diterapkanya Kurikulum 2013 di sekolah-sekolah beberapa tahun lalu, harus diakui bahwa situasi ini sedikit banyak telah memulai reformasi paradigma pembelajaran di Indonesia yang relevan dengan kebutuhan zaman. Paradigma pembelajaran lama yang didominasi Teacher Center secara berangsurangsur dibenahi menjadi paradigma pembelajaran berbasis Student Center pada kurikulum ini. Bagi guru, keberedaan kurikulum 2013 telah membawa angin segar dari sisi eksplorasi kemampuan peserta didik didalam pembelajaran Sejarah. Dengan kata lain, peran sebagai fasilitator dalam pembelajaran, membuat guru dituntut untuk selalu memberikan pengalaman belajar yang terstruktur bagi peserta didik dengan memanfaatkan tataran kontekstual sebagai sumber belajar Sejarah. Jika dicermati, proses pembelajaran yang demikian memang membutuhkan suatu pendekatan pembelajaran yang tepat. Mengenai dasar teori yang tepat untuk mengungkap pendekatan pembelajaran yang berorientasi pada peserta didik kiranya karya Lev Vygotsky tentang teori belajar konstruktivisme dapat menjadi rujukan menarik.

Keyakinan tokoh-tokoh konstruktivisme termasuk Vygotsky menunjukkan bahwa pengetahuan peserta didik harus dibangun dari realitas lapangan. Implikasi pemikiran Vygotsky dalam pembelajaran dibangun berdasarkan pertimbangan bahwa perkembangan kognitif peserta didik disamping ditentukan individu secara aktif juga dipengaruhi oleh lingkungan sosialnya. keterangan ini sesungguhnya menunjukkan bagaimana pentingnya pemberian Scaffolding bagi peserta didik serta penerapan model-model pembelajaran kooperatif dalam pembelajaran sehingga mampu menghasilkan individu yang memiliki kemampuan berfikir untuk menyelesaikan permasalahan.

Berangkat dari, asumsi bahwa Zone of Proximal Development dapat berjalan optimal apabila guru sebagai pembelajar mampu mentransmisikan berbagai macam pengetahuan, sikap, dan keterampilan yang proporsional kepada peserta didik. Indikator keberhasilan dari strategi ini ialah merujuk pada peningkatan kualitas sumber daya manusia yang termaktub dalam diri peserta didik. Adapun ciri-cirinya adalah muncul kesadaran dalam diri peserta didik untuk membuat hipotesis, lalu mengujinya, mencari persoalan, menemukan solusi, mengadakan renungan serta mengekspresikan ide dan gagasan. Berdasarkan kenyataan tersebut, maka guru perlu mengupayakan terciptanya nuansa pembelajaran yang mampu memberi ruang bagi peserta didik untuk mengembangkan kebutuhan pola pikirnya agar sesuai dengan harapan dan potensi diri mereka masingmasing. Dalam perspektif pembelajaran sejarah, keberadaan lokal history adalah ruang yang tepat untuk membantu perkembangan nalar serta naluri kepekaan peserta didik dalam menggauli berbagai kearifan yang menjadi identitas daerahnya.

Hasil refleksi terhadap berbagai persoalan yang ditemui pada saat pembelajaran menunjukkan bahwa peserta didik sejatinya juga membutuhkan 
asupan dan nutrisi terkini, utamanya memang dalam pengembangan materi ajar yang sepadan antara local history dan official history. Pada ranah pengembangan materi tersebut, sesungguhnya sulit untuk mencapai kesetaraan dalam tataran praktisnya sehingga salah satu, memang seyogyanya menempati kedudukan dominan. Asumsi yang berkembang dibenak peneliti dalam menyikapi persoalan ini memang dipengaruhi oleh pemikiran R.Moh Ali tentang pembabakan sejarah Indonesia pada ranah nasional dan tataran lokal. ${ }^{14}$ Belakangan dengan semakin mengemukanya penerapan kurikulum 2013 pada ranah pendidikan ternyata turut membawa angin segar bagi keberadaan local history.

Mengenai pentignya local history (Sejarah Lokal) Mulyana dan Restu menyatakan, "Kajian tentang sejarah dunia yang jauh dari lokalitas para peserta didik, serta sejarah nasional yang tidak mengakomodasi karakteristik daerah setempat dapat dikembangkan secara kontekstual sesuai dengan persoalanpersoalan yang dihadapi oleh para peserta didik di daerah setempat" ${ }^{15}$ Agaknya dari realita yang terbentang menunjukkan bahwa, keberadaan local history dalam pengajaran sedikit banyak telah berkontribusi memunculkan the other dalam narasi sejarah sehingga dominasi the great man theory yang termakhtub didalam ranah historiografi Indonesia dapat terkondisikan.

\section{Pembelajaran Resolusi Konflik Berbasis Teks Kajen dan Serat Cebolek}

Indonesia sebagai sebuah nation (bangsa) merupakan entitas dari sekumpulan penjuru keberagaman nusantara yang terintegrasi dalam satu kesatuan identitas kenegaraan. Keberagaman dan kemajemukan yang termaktub pada negara Indonesia merupakan gerbang menuju kemaslahatan dan kesejahteraan bangsa apabila seluruh elemen didalamnya mampu bersinergi secara optimal. Akan tetapi upaya mewujudkanya memang bukan perkara mudah, jika kita menilik situasi dan kondisi terkini yang dialami bangsa Indonesia belakangan ini. akhir-akhir ini keharmonisan yang dirajut dan dipelihara bersama oleh masyarakat banyak menuai polemik, khususnya pada ranah pemahaman dan penghayatan terhadap hakekat kehidupan beragama. Banyaknya kasus intoleran, sikap fanatisme, dan penyerangan terhadap para pemuka agama belakangan ini seringkali menimbulkan ketegangan dan konflik yang berujung pada pengadilan paradigma. Islam sebagai agama mayoritas di negeri ini serta ajaranya yang lekat dengan dimensi kemanusiaan tentu memiliki peran yang cukup strategis dalam penuntasan berbagai persoalan tersebut sehingga kehadiranya melalui penelusuran sejarah begitu penting untuk kontekstualisasi pemahaman resolusi konflik.

Bersumber pada salah satu kearifan lokal nusantara, kita akan melihat bagaimana metode resolusi konflik bercorak Islam menghiasi penuntasan

14 Ali, R. Moh, Pengantar Ilmu Sejarah Indonesia, (Yogyakarta: PT.LKIS Pelangi Aksara, 2005), 78 15 Mulyana, Agus, dan Gunawan Restu, Sejarah Lokal Penulisan dan Pembalajaran di Sekolah,

(Bandung: Salamina Press, 2007). 45 
persoalan-persoalan keagamaan Kerajaan Mataram Islam yang saat itu berkedudukan di Kartasura (belahan awal abad 18). Local history yang dimaksud sebagai sumber primer tersebut adalah manuskrip Teks Kajen dan Serat Cebolek. Ditinjau dari kandungan isi dan makna yang termaktub didalamnya, kedua manuskrip tersebut dapat dikategorikan sebagai karya sastra berbentuk ajaran piwulang (pendidikan) sehingga layak digunakan untuk kebutuhan bahan ajar. Selain itu, narasi sejarah yang termuat didalam kedua manuskrip tersebut pada dasarnya memiliki kesamaan, yakni menceritakan secara kronologis tentang penuntasan kasus yang dialami Syaikh Ahmad Mutamakkin.16

R.Ng. Yasadipura I (pengarang Serat Cebolek) menguraikan bahwa, Ahmad Mutamakkin yang dituduh sebagai ulama heretik (menyimpang) dari ajaran agama tidak jadi mendapatkan hukuman mati sehingga nasibnya lebih beruntung dibandingkan dengan para ulama-ulama terdahulu pengembang Tassawuf falsafi seperti (Syaikh Siti Jenar, Sunan Panggung, Syaikh Amongraga, dan Ki Bebeluk). Pembatalan hukuman tersebut terjadi ditengah memanasnya hubungan antara Ahmad Mutamakkin dengan para ulama-ulama penentangnya yang diwakili oleh Ketib Anom Kudus. Dalam dialog dengan Raden Demang Urawan sewaktu persidangan di Kartasura, Ketib Anom Kudus begitu tegas menentang keputusan amnesti terhadap ulama-ulama yang telah mengajarkan ilmu hakekat dan menafikan syariah seperti Ahmad Mutamakkin. Alasanya, ajaran hakekat yang dikemas Ahmad Mutamakkin melalui Serat Dewaruci rawan menimbulkan kesesatan akidah bagi khalayak luas apabila tidak diawali dengan pemahaman akan keutamaan syariah. ${ }^{17}$ Ketib Anom Kudus memandang bahwa, ajaran yang dikembangkan Ahmad Mutamakkin setara dengan doktrin hulul Al-Hallaj serta Wahdatul wujud dari Ibnu Al-Araby. ${ }^{18}$ Selain itu, dalam perspektif Ketib Anom, Ahmad Mutamakkin tidak pantas dinisbatkan sebagai ulama. Hal, tersebut terjadi karena Ahmad Mutamakkin telah melanggar syariat dengan memelihara dan menamai anjing peliharaanya serupa nama penghulu Tuban, yakni yang terbesar dinamai Komarrudin serta Abdul Qahar untuk nama anaknya.

Kedua perilaku tersebut terekam jelas didalam pupuh-pupuh (bait-bait) Serat Cebolek sehingga membuat ajaran (esoteris) Ahmad Mutamakkin menjadi sangat kontroversial kala itu. Akan tetapi meskipun para ulama yang dimotori Ketib Anom Kudus menganggap perilaku heretic dan kontroversial Ahmad Mutamakkin menyimpang dari syariat Islama namun tetap saja tidak dapat mengintervensi keputusan keraton. Pakubuwono II sebagai penguasa politik kala itu memutuskan tetap memberikan amnesti kepada Ahmad Mutamakkin karena memandang ajaranya hanya untuk dirinya sendiri bukan bagi khalayak luas. Secara keseluruhan, kandungan Serat Cebolek memang memiliki kesamaan narasi

16 Muslikh, K., I Samroni, B Suprojo, dan L.M. Fauzi. Teks Kajen dan Serat Cebolek sebagai Model Pembelajaran Resolusi Konflik: Studi Metaetika... 45. (scond citation and beyond,etc)

17 Depdikbud, Serat Cebolek. 1st. (Jakarta: Proyek Penerbitan Buku Sastra Indonesia dan Daerah, 1981), 86

18 Milal, Zainul Bizawie. Syekh Mutamakkin: Perlawanan Kultural Agama Rakyat... 87. (scond citation and beyond,etc) 
dengan teks-teks terdahulu yang menceritakan pertentangan agama di tanah Jawa. Akan tetapi bila dicermati lebih mendalam khususnya pada bagian akhir teks terdapat perbedaan yang signifikan. Serat Cebolek menyajikan babak akhir cerita pertentangan agama antara Syaikh Ahmad Mutamakkin dan Ketib Anom Kudus dengan sangat dramatis terutama pada fase penuntasan kasus yang berujung dengan terciptanya rekonsiliasi, sedangkan teks-teks terdahulu mengisahkan sebaliknya, yaitu lebih mengedepankan hukuman mati bagi pihakpihak yang dianggap heretic (menyimpang) dari ketentuan.

Selain Serat Cebolek, sumber lain yang menarasikan penuntasan kasus Syaikh Ahmad Mutamakkin adalah Teks Kajen. Secara harfiah, Teks Kajen merupakan kumpulan dari oral history (sejarah lisan) yang berkembang dan dituturkan oleh masyarakat Kajen, yakni sebuah tempat dikawasan Kabupaten Pati sekarang. Dari penelusuran informasi serta bukti-bukti yang bersandar pada pendekatan primary resources stricly menunjukkan bahwa, wilayah kajen pada dasawarsa ketiga abad 18 merupakan pusat kegiatan dakwah Syaikh Ahmad Mutamakkin. ${ }^{19}$ Oleh sebab itu, meskipun dalam perspektif historis kebenaran narasi Teks Kajen masih meragukan akan tetapi keberedaanya cukup memberikan kontribusi, setidaknya untuk mengungkap tentang penuntasan kasus tuduhan penyimpangan agama (heretic) yang dialamatkan pada diri Syaikh Ahmad Mutamakkin.

Pengkajian secara mendalam terhadap isi kandungan kedua naskah tersebut (Teks Kajen dan Serat Cebolek) menghasilkan pelbagai keputusan penting yang ditempuh penguasa politik kala itu untuk menuntaskan kasus (resolusi konflik) Syaikh Ahmad Mutamakkin. Pakuwono II sebagai penguasa politik kala itu menganggap bahwa, perdebatan-perdebatan yang timbul akibat kasus tersebut telah mengganggu keamanan dan stabilitas kerajaan. Hal ini menjadi sebuah ironi, mengingat saat itu kalangan istana sedang gencar-gencarnya menggalakkan konsepsi raja-sufi untuk kepentingan legitimasi kekuasaan. Konsepsi raja-sufi sendiri merupakan gagasan dari nenek Pakubuwono II yang ingin mempertegas kedudukan cucunya sebagai penguasa mataram kala itu. Oleh karenanya, raja kemudian mengutus dua orang kepercayaanya yakni, Patih Danureja dan Raden Demang Urawan untuk menyelidiki ajaran yang sebenarnya dikembangkan oleh Syaikh Ahmad Mutamakkin.

Hasil investigasi yang dilakukan keduanya berhasil membuahkan kesimpulan mengenai isi ajaran Syaikh Ahmad Mutamakkin yang selama ini menimbulkan preseden negatif dari pelbagai ulama penentangnya. Setelah itu, raja kemudian mengeluarkan fatwa tentang pengampunan terhadap diri Syaikh Ahmad Mutamakkin dan menyuruhnya agar menghindari perilaku serupa untuk menghindari kegaduhan-kegaduhan yang bisa timbul akibat perilakunya. Untuk memperjelas kembali bagaimana peran Pakubuwono II dan abdi negaranya dalam

19 Milal, Zainul Bizawie. Syekh Mutamakkin: Perlawanan Kultural Agama Rakyat... 88. (scond citation and beyond,etc) 
menuntaskan kasus Syaikh Ahmad Mutamakkin, berikut akan disajikan pemetaan resolusi konflik dari peristiwa tersebut: ${ }^{20}$

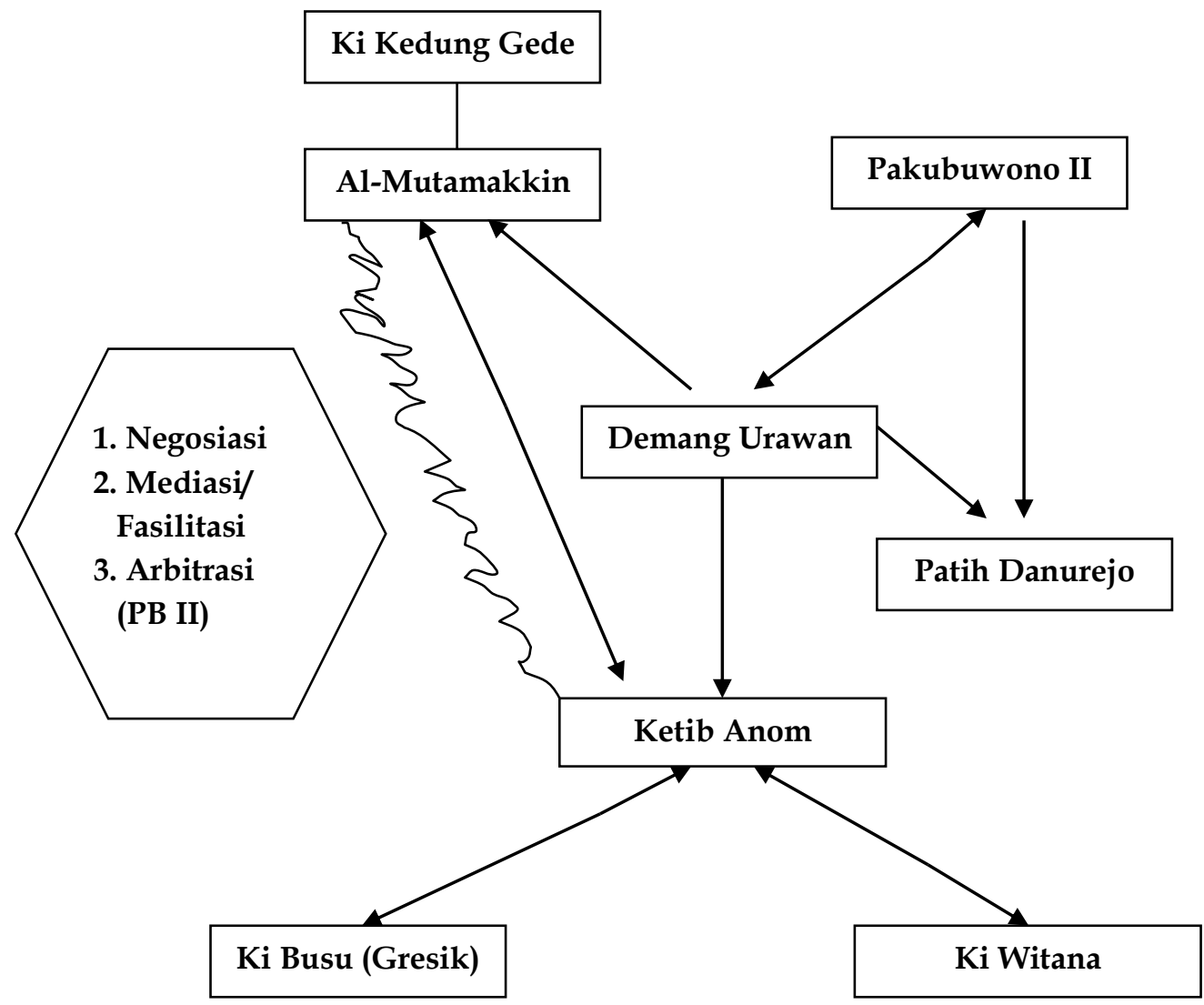

Gambar 1. Pemetaan resolusi konflik berdasarkan Serat Cebolek dan Teks Kajen

\section{Keterangan:}

1. Kotak menunjukkan pihak-pihak yang terlibat dalam situasi

2. Hexagon menunjukkan jalan penyelesaian konflik

3. Tanda panah menunjukkan alur komunikasi

4. Tanda zig-zag menunjukkan perselisihan/ konflik

\section{Pendekatan model Ways of Knowing Juergen Habermas}

Model Ways of Knowing merupakan salah satu aliran didalam pedagogi kritis (Critical Pedagogy) yang menekankan pentingnya keutamaan refleksi kritis dan emansipatoris dalam menyikapi interpretasi sejarah serta relevansinya terhadap persoalan-persoalan kontemporer. Secara harfiah, model Ways of Knowing menggambarkan bagaimana laju pemikiran salah seorang pakar critical teorist tersohor abad 20 dari mazhab Frankfurt yakni, Juergen Habermas yang bersifat eklektis. Bagi khalayak umum, Pola pemikiran Habermas cenderung sulit dipahami karena mempertautkan aliran Marxisme dengan pelbagai aliran besar lainya seperti Hermeneutics, Piagetian-Kolbergian, Developmentalism, Chomskyan-

20 Muslikh, K., I Samroni, B Suprojo, dan L.M. Fauzi. Teks Kajen dan Serat Cebolek sebagai Model Pembelajaran Resolusi Konflik: Studi Metaetika... 46. (scond citation and beyond,etc) 
linguistic dan Psychoanalysis.21 Meskipun begitu, hasil pemikiran Habermas kemudian mampu mencetuskan pelbagai keajaiban pada ruang pemikiranya yang kemudian termanifestasikan dalam upayanya untuk mengembangkan falsafah teori kritis.

Sikap eklektis Juergen Habermas dalam mengembangkan teori kritis telah berkontribusi menghasilkan knowledge-constitue interest atau cognitive interests. ${ }^{22}$ Keberadaan interest mampu menstimulasi manusia untuk memproduksi pengetahuan serta mengembangkanya menjadi sebuah budaya didalam komunitas dan masyarakatnya melalui prosess of knowing. ${ }^{23}$ Sebagai acuanya adalah aktivitas manusia dalam kehidupan sehari-hari yang dapat mencerminkan adanya suatu upaya dalam memproduksi pengetahuan yang berguna untuk menunjang kebutuhan hidupnya. Adanya hasrat kepentingan telah menstimulasi manusia untuk mengupayakan penguasaan secara teknik sehingga mendorong mereka memahami tentang benda fisik, fakta, atau tokoh (figure). Dengan demikian, hal inilah yang secara langsung telah menstimulasi manusia untuk melakukan analisi-empiris dalam prosess of knowing yang memunculkan budaya positivistik dalam menyenangkan hasrat penguasaan yang bersifat teknis dalam kehidupanya.

Hasrat manusia untuk mempertahankan kedudukanya sebagai knower mampu menstimulasi mereka agar senantiasa mengupayakan refleksi secara kritis (critical reflection) terhadap persoalan yang menjadi kepentingan utama sehingga mendorong timbulnya spirit dari dalam diri (self determination) untuk menekuni peranya sebagai agent of knowing.

\section{Implementasi Konsep dan Pertanyaan Emasipatoris Model Ways Of Knowing dalam ranah Pembelajaran Sejarah}

Pertanyaan-pertanyaan kritis model ways of knowing yang dikembangan Juergen Habermas pada dasarnya memungkinkan terjadinya dialog yang bersifat emansipatoris antara pembelajar (guru) dengan peserta didik dalam pembelajaran Sejarah. Secara khusus, terjadinya dialog emansipatoris dan partisipatif mampu mengkonstruksi pemikiran (minsed) peserta didik tentang pentingnya kesadaran kritis sebagai upaya mereduksi keberadaan distorsi yang tercipta dari sebuah proses interpretasi terhadap suatu peristiwa sejarah (Habermas, 1984). Selain itu, upaya ini juga telah berhasil mereformasi pembelajaran sejarah yang lebih menekankan pentingnya sebuah kegiatan refleksi bagi pembelajar (guru) dalam menegakkan sendi-sendi emansipasi didalam mata pelajaran yang diampunya

21 Habermas, Jurgen, The Theory Of Communicative Action, Volume One:Reason and

Rationalization of Society... 178. (scond citation and beyond,etc)

22 Supriatna, Nana. "Konstruksi Pembelajaran Sejarah yang berorientasi pada Masalah

Kontemporer Pembangunan." Mimbar XXVII. No 1 (2011). 1-10. Accessed 11-04-2018

https://ejournal.unisba.ac.id/index.php/mimbar/article/view/308

23 Lovat, T. J. "Ways of Knowing in Doctoral Examinations: How Examiners Position Themselves

in Relation to the Doctoral Candidates." Australian Journal of Education \& Developmental

Psychology 4 (2004). 11-20. Accessed 11-04-2018 https://files.eric.ed.gov/fulltext/EJ815558.pd 
sehingga dapat memberikan kesempatan lebih luas kepada peserta didik untuk mendialogkan materi sejarah. ${ }^{24}$

Berangkat dari perspektif pandangan kritis (critical theory) dan postmodernism dengan mengajukan pertanyaan pertanyaan emansipatoris model ways of knowing kepada peserta didik didalam pembelajaran yang menempatkan mereka sebagai subjek aktif dan otonom, maka diharapkan mampu mengkonstruksi paradigma berfikir mereka menuju sebuah proses kebijaksanaan. Dalam mengimplementasikan model ways of knowing pada ranah pembelajaran Sejarah, guru kemudian menyusun pelbagai pertanyaan-pertanyaan yang bersifat kritis dan emansipatoris. Pertanyaan penting yang diajukan misalnya, (1) Bagaiamana ajaran Syaikh Ahmad Mutamakkin dalam mendakwahkan agama Islam di Jawa kala itu?, (2) Mengapa sosok beliau (Ahmad Mutamakkin) mendapat preseden negatif didalam Serat Cebolek? Serta, (3) Hikmah apa yang dapat dipetik dari penuntasan kasus Syaikh Ahmad Mutamakkin?. Pelbagai pertanyaan-pertanyaan kritis dan emansipatoris tersebut merupakan strategi untuk mengajak peserta didik untuk turut menjadi pelaku sejarah pada zaman itu melalui relasi antara topik (pokok bahasan) dengan permasalahan-permasalahan yang termakhtub didalam Serat Cebolek dan Teks Kajen.

\section{Sintaks Model Pembelajaran Sejarah Islam dengan Pendekatan Ways Of Knowing}

Proses Implementasi model pembelajaran pada dasarnya memerlukan pelbagai landasan berpikir dalam mempertautkan konsep teori dengan tatara praktis. Oleh karenanya, pembelajar perlu memperhatikan kaedah-kaedah yang akan dijadikan pedoman utama. Terdapat beberapa kaedah-kaedah yang harus dipenuhi oleh pembelajar (guru) sebelum memulai tahapan-tahapan pengintegrasian kajian local history dalam materi ajar yang termuat dalam kurikulum. Pertama, ranah pengintegrasianya bukan pada ruang official history (Sejarah Indonesia), melainkan terdapat dalam mata pelajaran Sejarah Peminatan yang memang telah didesain untuk dapat mengakomodasi komponen-komponen local history. Kedua, keberadaan local history harus relevan dengan prinsip-prinsip kebutuhan serta kesesuaian dengan Kompetensi Dasar (KD) yang ada di kurikulum. Bagi para guru mata pelajaran sejarah, tahapan ini tentu tidak bisa diabaikan sebab nantinya proses tersebut akan menjadi landasan utama dalam penyusunan Rencana Pelaksanaan Pembelajaran (RPP) yang relevan serta dapat mengakomodasi kajian local history didalam pembelajaran. Ketiga, penyusunan serta penetapan item-item instrumen pengukuran, penilaian, dan penskoran yang reliabel dan valid sehingga implementasinya sesuai dengan kaedah-kaedah evaluasi pembelajaran.Pemilihan Teks Kajen dan Serat Cebolek sendiri sebagai contextual learning memang tidak terlepas dari hasil refleksi yang dilakukan oleh penulis. Refleksi tersebut merupakan kumpulan pengalaman penulis selama menjadi guru mata pelajaran sejarah di SMA Batik I Surakarta. Kekosongan bahan

24 Supriatna, Nana. "Konstruksi Pembelajaran Sejarah yang berorientasi pada Masalah Kontemporer Pembangunan." 
ajar pada kajian sejarah kesusastraan Jawa menjadi titik awal bagi penulis untuk melakukan riset guna mengisi ruang kosong tersebut. Penulis memandang bahwa keberadaan sejarah kesusastraan Jawa perlu untuk diajarkan kepada peserta didik karena mengandung pelbagai nilai-nilai moral yang tentunya sangat berguna bagi keberlangsungan kehidupan. Selain itu, penulis menganggap bahwa, selama ini keberadaan materi Kerajaan Mataram Islam didalam buku teks masih didominasi narasi-narasi sejarah dengan tajuk politik dan suksesi yang terkadang diwarnai pertumpahan darah. Sebagai contoh, keberadaan perang suksesi Jawa I,II, dan III dalam perjalanan sejarah Kerajaan Mataram Islam yang dipenuhi intrik-intrik kekerasan dan sarat akan terjadinya pertumpahan darah antar saudara tentunya perlu didekontruksi dalam ranah materi ajar. Hal tersebut terkait dengan kedudukan pembelajaran Sejarah, yang semestinya mampu memberadabkan para peserta didik menjadi insan yang bijaksana dan beretika serta jauh unsur-unsur kekerasan, perilaku intoleran dan sikap fanatisme yang berlebihan. Adapun sintaks pembelajaran Sejarah Islam berbasis Teks Kajen dan Serat Cebolek adalah sebagai berikut:

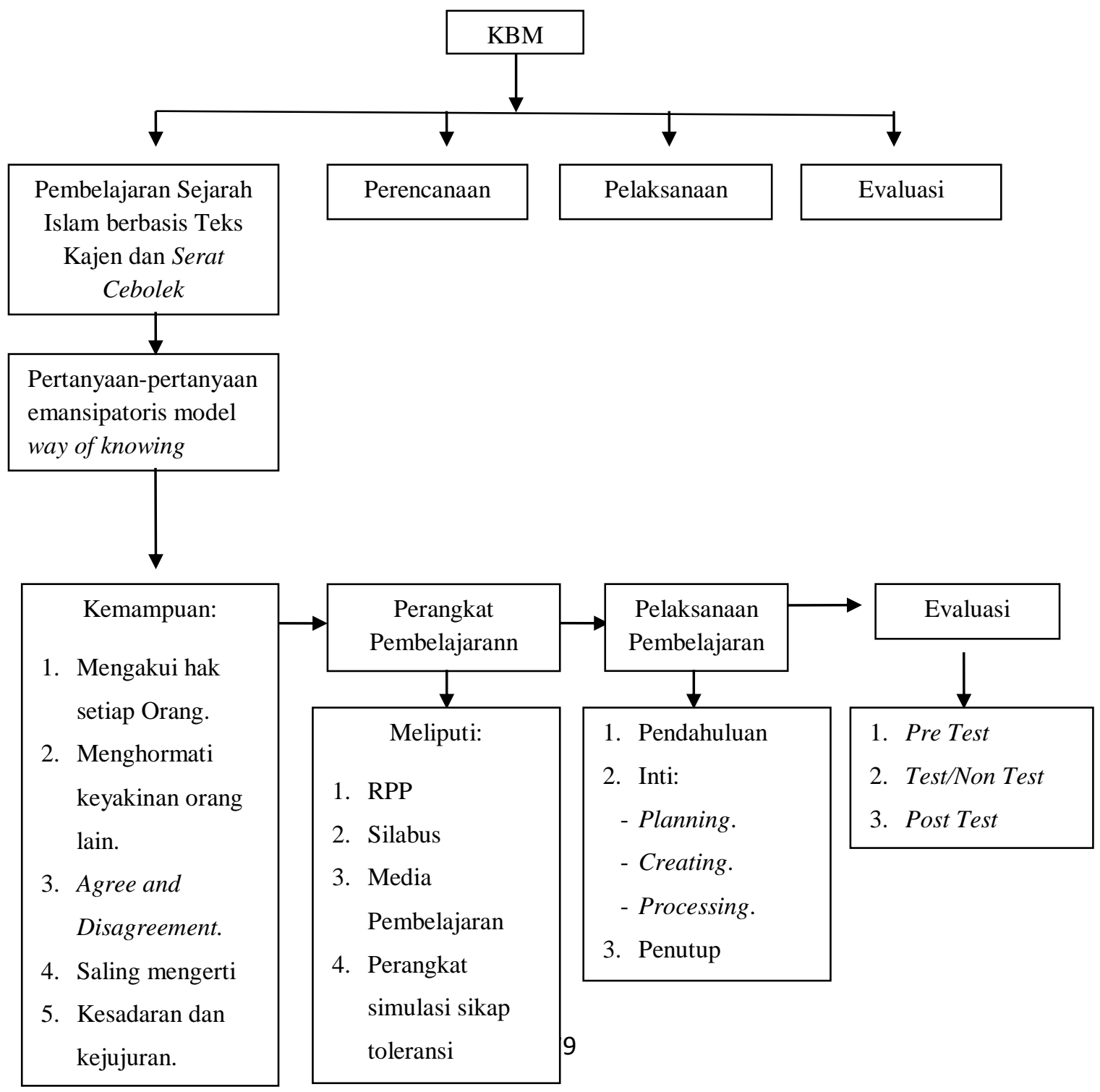




\section{KESIMPULAN}

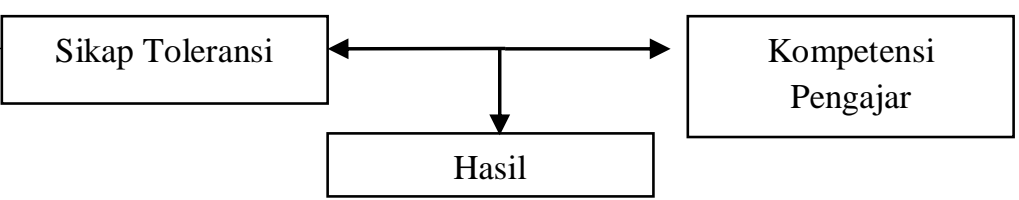

Gambar 2. : Sintaks Pembelajaran Sejarah

Persoalan serius yang menimpa bangsa Indonesia akhir-akhir ini mengarah pada permasalahan-permasalahan dari pelbagai isu-isu sensitif yang menjurus pada menguatnya ideologi fanatisme dan radikalisme dilingkungan masyarakat luas. Kedua ideologi tersebut (fanatisme maupun radikalisme) merepresentasikan sebuah pertentangan dengan Pancasila sebagai ideologi utama dari bangsa Indonesia. Apabila pertentangan ini terus terpelihara, maka hanya akan menyebabkan terjadinya konflik dengan skala luas yang berujung pada terciptanya disintegrasi bangsa. Oleh sebab itu, dalam menanganinya memang diperlukan sinergi dari pelbagi pihak agar bersatu untuk mengenyahkan kedua ideologi tersebut dari kehidupan masyarakat Indonesia. Salah satunya ialah dengan melibatkan peran serta pendidikan dalam mengurai perasaan fanatik serta berupaya mengintensifkan deradikalisasi dikalangan generasi penerus bangsa.

Tidak bisa dipungkiri, pendidikan memang memegang peranan penting dalam pembentukan karakter sebuah bangsa. Salah satu aspek didalam pendidikan yang mengiringi pembentukan dan perjalanan sebuah bangsa ialah Sejarah. Tanpa Sejarah, negara Indonesia takkan pernah memiliki mentalitas yang memadai dalam mengarungi bahtera kehidupan berbangsa didalam sanubari masyarakatnya. Berangkat dari perspektif tersebut, maka sudah seyogyanya pelbagai pihak yang terkait dengan pembelajaran Sejarah kemudian melakukan refleksi dan pembenahan. Dalam perspektif postcolonial, Sejarah mempunyai tugas untuk membebaskan bangsa ini dari belenggu persoalan-persoalan esensial seperti keberadaan fanatisme serta radikalisme yang kian hari makin memprihatinkan eksitensinya. Oleh sebab itu, dewasa ini pengayaan sumbersumber pembelajaran sejarah merupakan suatu keharusan terutama yang mempunyai esensi serta kedekatan emosi dengan peserta didik.

Upaya mengkonstruksi pembelajaran sejarah Islam berbasis Teks Kajen dan Serat Cebolek adalah salah satu dari sekian upaya yang menunjukkan inovasi seorang guru dalam mengajar. Dengan pemahaman resolusi konflik yang termakhtub didalam kedua naskah klasik tersebut, guru kemudian mengajak peserta didik untuk memerankan pelaku sejarah dizamanya agar mereka mampu menghayati nilai-nilai keutamaan bahtsul masail, tabayun, hakam, dan islah. 


\section{DAFTAR PUSTAKA}

Ali, R. M., 2005. Pengantar Ilmu Sejarah Indonesia. Yogyakarta: PT.LKIS Pelangi Aksara.

Azra, A., 1999. Esai-esai Intelektual Muslim dan Pendidikan Islam. Jakarta: Logos.

Bertens, K., 1990. Filsafat Barat abad XX Inggris-Jerman. Jakartsa: Gramedia.

Depdikbud, 1981. Serat Cebolek. 1st ed. Jakarta: Proyek Penerbitan Buku Sastra Indonesia dan Daerah.

Goldstein, L. J., 1961. Book Reviews: Class and Class Conflict in Industry Society. Ralf Dahrendorf. Ethics Volume 71, Number 2, pp. 142-143.

Habermas, J., 1984. The Theory Of Communicative Action, Volume One:Reason and Rationalization of Society. Boston: Beacon Press.

Hillenbrand, C., 2005. Perang salib: sudut pandang Islam. Jakarta: Serambi.

Loombard, D., 2008. Nusa Jawa: Silang Budaya, Kajian Sejarah Terpadu bagian I: Batasbatas Pembaratan. Jakarta: Gramedia Pustaka Utama.

Lovat, T. J., 2004. Ways of Knowing in Doctoral Examinations: How Examiners Position Themselves in Relation to the Docyoral Candidates. Australian Journal of Education \& Developmental Psychology, Volume 4, pp. 11-20.

Milal, Z. B., 2014. Syekh Mutamakkin: Perlawanan Kultural Agama Rakyat. Jakarta: pustaca compass.

Mulyana, A. \& Restu, G., 2007. Sejarah Lokal Penulisan dan Pembalajaran di Sekolah. Bandung: Salamina Press.

Muslikh, K., Samroni, I., Suprojo, B. \& Fauzi, L., 2011. Teks Kajen dan Serat Cebolek sebagai Model Pembelajaran Resolusi Konflik: Studi Metaetika. Yogyakarta: Kaukaba.

Panggabean, R., 2014. Islam Indonesia: Satu Islam Untuk Semua. Gap Informasi Picu Konflik Agama, Senin Januari, pp. 1-2.

Ricklefs, M. C., 2016. Sejarah Indonesia Modern. Yogyakarta: Gadjah Mada University Press.

Sariyatun, 2013. Pengembangan Model Pendidikan Nilai-Nilai Budaya Di SMP Berbasis Tradisi Seni Batik Klasik Surakarta. Paramita Volume 23, No.2, pp. 230-241.

Sukmadinata, N. S., 2013. Metode Penelitian Pendidikan. Bandung: PT Remaja Rosdakarya. 
Supriatna, N., 2011. Konstruksi Pembelajaran Sejarah yang berorientasi pada Masalah Kontemporer Pembangunan. Mimbar, XXVII(1), pp. 1-10.

Yunus, F. M., 2014. Konflik Agama di Indonesia Problem dan Solusi Pemecahanya. Substantia, Volume 16 Nomor 2, pp. 1-12. 